\title{
Front Matter: Volume 11101
}

, "Front Matter: Volume 11101," Proc. SPIE 11101, Material Technologies and Applications to Optics, Structures, Components, and Sub-Systems IV, 1110101 (16 October 2019); doi: 10.1117/12.2551006

SPIE Event: SPIE Optical Engineering + Applications, 2019, San Diego, California, SPIE. United States 


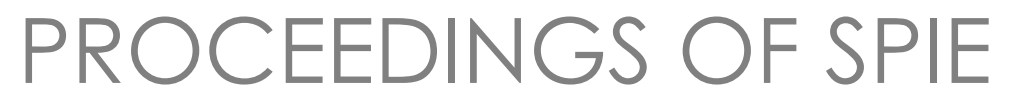

\section{Material Technologies and Applications to Optics, Structures, Components, and Sub-Systems IV}

Matthias Kroedel

Bill A. Goodman

Editors

12 August 2019

San Diego, California, United States

Sponsored and Published by

SPIE

Volume 11101 
The papers in this volume were part of the technical conference cited on the cover and title page. Papers were selected and subject to review by the editors and conference program committee. Some conference presentations may not be available for publication. Additional papers and presentation recordings may be available online in the SPIE Digital Library at SPIEDigitalLibrary.org.

The papers reflect the work and thoughts of the authors and are published herein as submitted. The publisher is not responsible for the validity of the information or for any outcomes resulting from reliance thereon.

Please use the following format to cite material from these proceedings:

Author(s), "Title of Paper," in Material Technologies and Applications to Optics, Structures,

Components, and Sub-Systems IV, edited by Matthias Kroedel, Bill A. Goodman, Proceedings of SPIE Vol. 11101 (SPIE, Bellingham, WA, 2019) Seven-digit Article CID Number.

ISSN: 0277-786X

ISSN: 1996-756X (electronic)

ISBN: 9781510628953

ISBN: 9781510628960 (electronic)

Published by

SPIE

P.O. Box 10, Bellingham, Washington 98227-0010 USA

Telephone +1 3606763290 (Pacific Time) · Fax +1 3606471445

SPIE.org

Copyright (C) 2019, Society of Photo-Optical Instrumentation Engineers.

Copying of material in this book for internal or personal use, or for the internal or personal use of specific clients, beyond the fair use provisions granted by the U.S. Copyright Law is authorized by SPIE subject to payment of copying fees. The Transactional Reporting Service base fee for this volume is $\$ 21.00$ per article (or portion thereof), which should be paid directly to the Copyright Clearance Center (CCC), 222 Rosewood Drive, Danvers, MA 01923. Payment may also be made electronically through CCC Online at copyright.com. Other copying for republication, resale, advertising or promotion, or any form of systematic or multiple reproduction of any material in this book is prohibited except with permission in writing from the publisher. The CCC fee code is $0277-$ $786 \mathrm{X} / 19 / \$ 21.00$.

Printed in the United States of America by Curran Associates, Inc., under license from SPIE.

Publication of record for individual papers is online in the SPIE Digital Library.

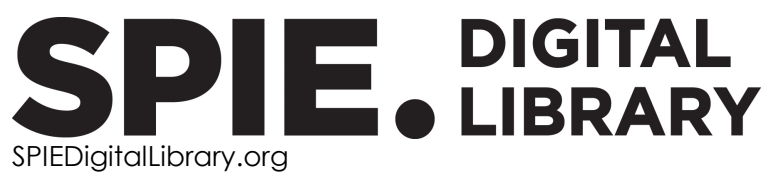

Paper Numbering: Proceedings of SPIE follow an e-First publication model. A unique citation identifier (CID) number is assigned to each article at the time of publication. Utilization of CIDs allows articles to be fully citable as soon as they are published online, and connects the same identifier to all online and print versions of the publication. SPIE uses a seven-digit CID article numbering system structured as follows:

- The first five digits correspond to the SPIE volume number.

- The last two digits indicate publication order within the volume using a Base 36 numbering system employing both numerals and letters. These two-number sets start with $00,01,02,03,04$, 05, 06, 07, 08, 09, OA, OB ... 0Z, followed by 10-1Z, 20-2Z, etc. The CID Number appears on each page of the manuscript. 


\title{
Contents
}

\author{
$\checkmark \quad$ Authors \\ vii Conference Committee
}

\section{SESSION $1 \quad$ CERAMICS AND COMPOSITES}

$1110102 \quad$ MTG star tracker assembly bracket: a successful story of fabrication of light-weighted structures [11101-1]

1110103 Silicon nitride for structural parts of space applications [1 $1101-3]$

1110104 Processing and characterization of nanoparticles and carbon nanotube reinforced continuous fiber ceramic nanocomposites by preceramic polymer pyrolysis (Invited Paper) [1 11 101-4]

1110105 Ceramic mould development for precision bending of thin glass [111101-5]

\section{SESSION $2 \quad$ FABRICATION PROCESSES}

1110106 Ultraprecise flat mirrors for the pointing unit of the DESIS instrument on board of the ISS [11101-6]

1110109 A novel approach of copper-ceramic-joints manufactured by selective laser melting [1 $1101-9]$

\section{SESSION $3 \quad$ SPECIAL MATERIALS AND APPLICATIONS}

$11101 \mathrm{OB} \quad$ High reflectance mirrors for micro-cavity applications [11101-22]

$111010 \mathrm{C}$ Heat accumulation effect existing in silicon substrate by femtosecond laser irradiation on antireflection performance [11101-12]

11101 OD The verification platform for the mosaic CCD camera in WFST [11101-13]

$111010 \mathrm{E}$ Understanding optical changes in on-orbit spacecraft materials [11101-14]

SESSION $4 \quad$ ADDITIVE MANUFACTURING

11101 OF Ultra-lightweight ultra-stable RoboSiC additively manufactured lasercom telescope (Invited Paper) [11101-16] 
$11101 \mathrm{OH} \quad$ Near-zero CTE 3D-printed RoboSiC deployable truss core structures with active precision adjustment [11101-18]

\section{SESSION 5 GLASS MATERIALS}

$111010 \mathrm{~J}$ Strength of Zerodur for mirror applications: follow-up [11101-20]

$111010 K \quad$ Active radome material [11101-21]

\section{POSTER SESSION}

$11101 \mathrm{OL} \quad$ New candidate substrate materials for space mirror optics [11101-2]

$111010 \mathrm{M}$ Design, manufacturing, and validation of the mirrors for an experimental Korsch telescope [11101-11] 


\section{Authors}

Numbers in the index correspond to the last two digits of the seven-digit citation identifier (CID) article numbering system used in Proceedings of SPIE. The first five digits reflect the volume number. Base 36 numbering is employed for the last two digits and indicates the order of articles within the volume. Numbers start with 00, 01, 02, 03, 04, 05, 06, 07, 08, 09, OA, OB...0Z, followed by 10-1Z, 20-2Z, etc.

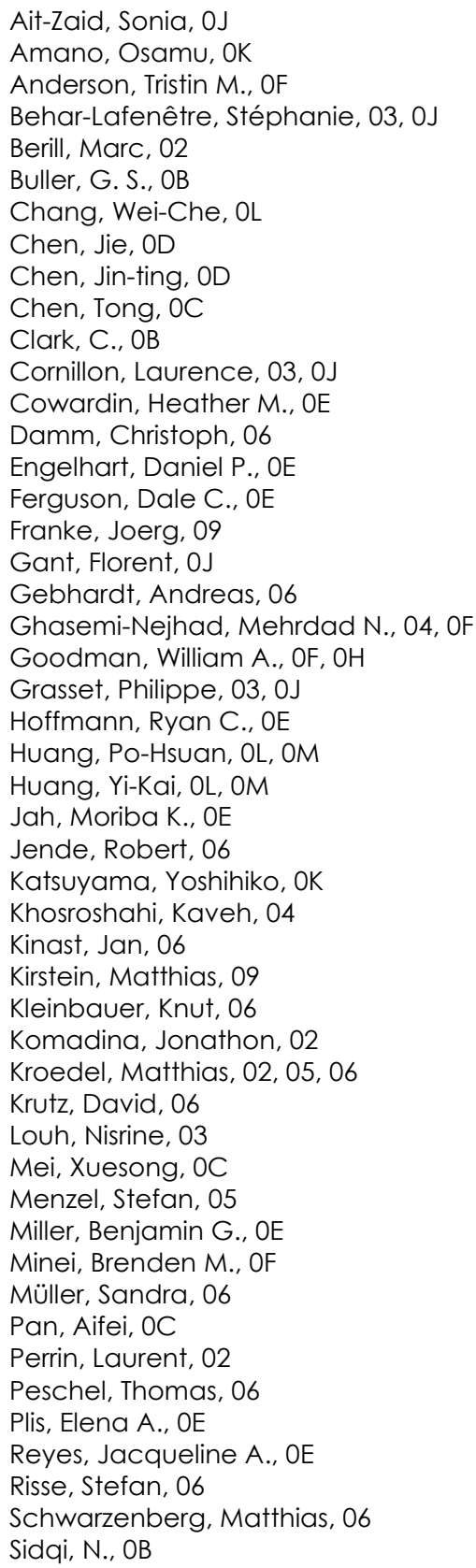

\author{
Stehlíková, Veronika, 05 \\ Stoll, Thomas, 09 \\ Stuecker, John N., OF \\ Such-Taboada, Miguel, 03 \\ Tao, Tao, OC \\ Umemoto, Tomohiro, OK \\ Walter, Ingo, 06 \\ Wang, Jian, OD \\ Wang, Wenjun, OC \\ Wu, Hsing-YU, OL \\ Zhang, Hong-fei, OD \\ Zhang, Jun, OD
}


Proc. of SPIE Vol. $111011110101-6$

Downloaded From: https://www.spiedigitallibrary.org/conference-proceedings-of-spie on 25 Apr 2023 Terms of Use: https://www.spiedigitallibrary.org/terms-of-use 


\section{Conference Committee}

Program Track Chair

H. Philip Stahl, NASA Marshall Space Flight Center (United States)

Conference Chairs

Matthias Kroedel, ECM Engineered Ceramic Materials GmbH (Germany)

Bill A. Goodman, Goodman Technologies LLC (United States)

Conference Program Committee

Ron Eng, NASA Marshall Space Flight Center (United States)

Jeong-Yeol Han, Korea Astronomy and Space Science Institute (Korea, Republic of)

Yoshihiko Katsuyama, Super Resin, Inc. (Japan)

William P. Kuhn, Opt-E (United States)

Rob Michel, Materion Technical Materials (United States)

Ted Mooney, Harris Corporation (United States)

Tsuyoshi Ozaki, Composites Research and Development Company, Ltd. (Japan)

John W. Pepi, L-3 Communications SSG-Tinsley (United States)

Stefan Risse, Fraunhofer-Institut für Angewandte Optik und Feinmechanik (Germany)

Michael N. Sweeney, General Dynamics-Global Imaging Technologies (United States)

Flemming Tinker, Aperture Optical Sciences Inc. (United States)

\section{Session Chairs}

1 Ceramics and Composites

Bill A. Goodman, Goodman Technologies, LLC (United States)

2 Fabrication Processes

Matthias Kroedel, ECM Engineered Ceramic Materials GmbH (Germany)

3 Special Materials and Applications

Jeong-Yeol Han, Korea Astronomy and Space Science Institute (Korea, Republic of) 
4 Additive Manufacturing

Matthias Kroedel, ECM Engineered Ceramic Materials GmbH (Germany)

5 Glass Materials

Stefan Risse, Fraunhofer-Institut für Angewandte Optik und Feinmechanik IOF (Germany) 